\title{
Evaluation of the Influence of Treatment Exposure on Neuropeptide Leptin Hormone and Obesity Risk among Jordanian Breast Cancer Women
}

\author{
Safa'a A. Al-Zeidaneen¹, Mousa N. Ahmad², Ali D. Al-Ebous ${ }^{3}$ \\ ${ }^{1}$ Department of Allied Medical Sciences, Al-Zarqa University College, Al-Balqa Applied University, Jordan \\ ${ }^{2}$ Department of Nutrition and Food Technology, Faculty of Agriculture, the University of Jordan, Amman, Jordan \\ ${ }^{3}$ Breast Cancer Unite, Department of General Surgery, King Hussein Medical Center, Amman, Jordan
}

\section{SUMMARY}

Breast cancer (BC) is the most prevalent and life-threatening malignant tumor in adult females. Little is known about the association between neuropeptide leptin hormone and development of BC.

The aim of the paper was to evaluate the interactive role of neuropeptide leptin hormone among BC Jordanian women with regard to treatment exposure and menopausal status.

A total of 396 BC women (25-65 years) attending BC clinics were evaluated by observational study. The experimental design permitted the inclusion of 134 newly diagnosed $B C$ patients who were not exposed to any type of interventions and 262 recently diagnosed BC patients during their first three months of treatment exposure. Manual enzyme-linked immunosorbent assay (ELISA) was used for the quantitative determination of leptin levels.

The prevalence of hyperleptinaemia, leptin level higher than $11.1 \mathrm{ng} / \mathrm{ml}$, was almost $27 \%$, and the mean value of serum leptin $(\mathrm{ng} / \mathrm{ml})$ in the whole sample was $8.5 \pm 0.03$ and it was insignificantly lower in non-chemo $(7.1 \pm 0.05)$ than chemo $(8.6 \pm 0.5)$ and newly diagnosed $(9.2 \pm 0.6) \mathrm{BC}$ patients. Leptin was positively correlated with all obesity indices including BMI, WC, WHpR and WHtR. In newly diagnosed BC patients, leptin had the highest correlation with BMI $(r=0.38, p<0.05)$, whereas in the recently diagnosed, it was highly correlated with $\mathrm{WC}(\mathrm{r}=$ $0.38, \mathrm{p}<0.05$ ).

The leptin hormone was positively correlated with obesity indices in BC patients and it was higher in postmenopausal $\mathrm{BC}$ women. The leptin hormone was decreased after treatment exposure and may be considered as a biomarker for $\mathrm{BC}$ prognosis and response to treatment. The leptin hormone may need a closer attention by health care providers in order to improve outcomes after making the diagnosis and treatment exposure.

Key words: breast cancer, cancer treatment, leptin hormone, neuropeptide, obesity, postmenopause 


\section{INTRODUCTION}

Leptin is a neuropeptide hormone produced by the obese (ob) gene. It is primarily expressed and secreted by adipocytes and acts through binding to receptors in the hypothalamus and peripheral tissues (1-3). It has a significant role in the chronic regulation of body weight and energy homeostasis by suppressing appetite, stimulating thermogenesis and increasing energy expenditure $(2,3)$. In addition, leptin level is shown to be positively associated with adipose mass (4). Several studies have reported other physiological functions of leptin such as metabolic, mutagenic and proangiogenic factors (5). Leptin acts through binding to the extracellular domain of specific membrane receptors in the class-I cytokine receptor family; six isoforms of the leptin receptor have been identified so far (2-3).

The association between leptin and breast cancer (BC) has been suggested by many studies but inconclusive results have been found. It is a mutagenic factor that is positively associated with BC through systemic effect as endocrine hormone and locally through paracrine and autocrine pathway $(6,7)$. Leptin synthesis in adipocytes is stimulated by different metabolic factors shown to be associated with neoplastic processes such as insulin, interleukins, glucocorticoids, reproductive hormones and prostaglandins (6). Leptin gene can be activated by cellular hypoxia that occurs frequently in solid tumors such as BC $(3,6)$. Furthermore, leptin may be related to BC through several mechanisms including neoangiogenesis, the formation of new blood vessels from preexisting vasculature, vascular remodeling and induces endothelium-dependent vasodilatation $(5,8)$.

In Jordan, no previous study has investigated the relationship between BC and leptin hormone. Furthermore, studies about the impact of BC-associated risk factors such as menopausal status, BC stage and treatments exposure on leptin level among Jordanian or nearby Arab countries are not available. In the present study, we aimed to evaluate the interactive role of neuropeptide leptin hormone among BC Jordanian women considering treatment exposure, BC severity and menopausal status.

\section{PATIENTS AND METHODS}

\section{Study sample and design}

In this study, 396 Jordanian BC patients aged 2565 years attending BC clinics at the Jordanian Royal Medical Services in Jordan for the management and follow- up of their conditions during the period from January 2013 to July 2014 were screened for leptin hormone level. The experimental design was prospective observational that permitted the inclusion of 134 newly diagnosed BC patients who were not exposed to any type of treatment interventions, and 262 recently diagnosed BC patients who were exposed to treatment interventions during the first three months of diagnosis. Recently diagnosed group was subdivided in two subgroups (chemo and nonchemo) to control the exposure to chemotherapy. The study design also permitted the inclusion of pre- and postmenopausal BC patients for hormonal balance control. The sample size (396) was statistically sound and accounted for about $50 \%$ of the BC cases in the year 2011. The median age of females with BC in Jordan is 51 years, and $80 \%$ of the cases were aged between 25 and 65 years (9). The patients were excluded if they had any clinical or laboratory evidence of congestive heart failure, coronary disease, chronic renal failure, polycystic ovary syndrome, thyroid diseases, pregnancy and lactation. All subjects who did not meet the inclusion criteria were excluded. The subjects below 25 or above 65 years of age, with type I diabetes mellitus, epilepsy and those taking medical herbs were also excluded. This study was conducted according to the Declaration of Helsinki (2008, including 2013 amendments) and written informed consent was obtained from all participants at the start of the study. The Royal Medical Services Ethical Committee approved this study (reference number 1/2013).

\section{Data collection}

A valid and reliable questionnaire was used for data collection which included personal information, health, anthropometric and biochemical measurements.

\section{Anthropometric measurements}

Anthropometric indicators including height, weight, waist circumference (WC) and hip circumference (HC) were measured in duplicates in subjects lightly clothed and without shoes. These indicators were performed by the investigator following the methodological protocol (10). Height was measured to the nearest 1.0 $\mathrm{mm}$ using a wall-mounted stadiometer and weight to the nearest $100 \mathrm{~g}$ using an electronic scale. The body mass index (BMI) was calculated as weight in kilograms divided by height in meters squared. The BMI $\geq 30$ $\mathrm{kg} / \mathrm{m}^{2}$ was considered obese (11). The waist to hip ratio (WHpR) was calculated as WC divided by HC, while 
the waist to height ratio (WHtR) was calculated as WC divided by height.

\section{Biochemical analyses}

The fasting blood samples were collected; then, the serum was harvested and stored at $-80^{\circ} \mathrm{C}$ for analysis. Biochemical measurements were analyzed in Princess Eman Center for Laboratory Research and Science. The following laboratory measurements were performed in duplicates for each subject and the mean values were taken in subsequent calculations for biomarkers such as fasting blood glucose (FBG), fasting blood insulin (FBI) and C-peptide. Plasma glucose was determined by the glucose dehydrogenase method (Wako Pure Chemical Industries, Ltd., Osaka, Japan). C-peptide was measured by a solid-phase, two-site chemiluminescent immunoassay (IMMULITE 2000 C-peptide assay, Siemens AG, Erlangen, Germany). The fasting blood insulin levels were quantitatively determined by chemiluminescent microparticle immunoassay (CMIA) technology (ARCHITECT Insulin assay, Abbott Laboratories, IL, USA). The manual enzyme-linked immunosorbent assay (ELISA) was used for the quantitative determination of leptin levels in serum by an enzyme immunoassay method (dbc-Diagnostics Biochem Canada Inc., Canada). The insulin sensitivity was then calculated using HOMA according to the following formula:

$\log (\mathrm{HOMA})=\log [\mathrm{FBG}(\mathrm{mmol} / \mathrm{L}) \times \mathrm{FBI}(\mu \mathrm{U} / \mathrm{ml}) / 22.5]$ (12).

Leptin has no universally accepted definition for the upper normal limits. For the purpose of this study, we considered participants having increased serum leptin levels, with serum leptin concentration $>11.1 \mathrm{ng} / \mathrm{ml}$, based on the previously published studies (13).

\section{Statistical analysis}

Statistical analyses were performed using Statistical Package for the Social Sciences (SPSS), version 10.0 (SPSS Inc., Chicago, USA). Differences were significant at $\mathrm{p}<0.05$. Results were expressed according to the study needs either as frequency distribution with their percentages $(\%)$ or means \pm standard error of mean (SEM). Frequency distribution and percentages or means \pm SEM were performed for the health characteristics, prevalence of high leptin level and to compare menopausal status among study groups. The independent sample t-test or the Chi-squared test were used testing the relationship between categorical variables such as leptin level and menopausal status.

\section{RESULTS}

The metabolic characteristics of leptin, C-peptide and HOMA according to treatment exposure are given in Table 1. None of metabolic characteristics showed significant differences ( $p \geq 0.05)$ among study groups. Leptin was lower $(p \geq 0.05)$ in non-chemo $(7.1 \pm 0.5 \mathrm{ng} / \mathrm{ml})$ compared to chemo $(8.6 \pm 0.5 \mathrm{ng} / \mathrm{ml})$ and newly diagnosed $(9.2 \pm 0.6 \mathrm{ng} / \mathrm{ml})$ groups. C-peptide and HOMA for the whole sample were $1.4 \pm 0.1 \mathrm{ng} / \mathrm{ml}$ and $3.6 \pm 0.2$, respectively.

Table 1. The metabolic characteristics of leptin, C-peptide and HOMA according to treatment exposure ${ }^{(1-3)}$

\begin{tabular}{|c|c|c|c|c|c|c|c|c|c|c|}
\hline \multirow{3}{*}{ Character } & \multirow{2}{*}{\multicolumn{2}{|c|}{$\begin{array}{c}\text { Newly } \\
\text { diagnosed } \\
(\mathrm{n}=134) \\
\end{array}$}} & \multicolumn{6}{|c|}{ Recently diagnosed $(\mathrm{n}=262)$} & \multirow{2}{*}{\multicolumn{2}{|c|}{$\begin{array}{c}\text { Whole } \\
\text { sample } \\
(\mathrm{n}=396) \\
\end{array}$}} \\
\hline & & & \multirow{2}{*}{\multicolumn{2}{|c|}{$\begin{array}{l}\text { Non-chemo } \\
(n=86) \\
\text { Mean } \pm \text { SEM }\end{array}$}} & \multirow{2}{*}{\multicolumn{2}{|c|}{$\begin{array}{c}\text { Chemo } \\
(\mathrm{n}=176)\end{array}$}} & \multicolumn{2}{|c|}{$\begin{array}{c}\text { Total } \\
(\mathrm{n}=262)\end{array}$} & & \\
\hline & Mec & SEM & & & & & Mea & & Mea & \\
\hline Leptin (ng/ml) & 9.2 & 0.6 & 7.1 & 0.5 & 8.6 & 0.5 & 8.1 & 0.4 & 8.5 & 0.3 \\
\hline C-Peptide (ng/ml) & 1.7 & 0.2 & 1.3 & 0.1 & 1.2 & 0.1 & 1.2 & 0.1 & 1.4 & 0.1 \\
\hline HOMA & 3.6 & 0.4 & 3.8 & 0.5 & 3.5 & 0.3 & 3.7 & 0.3 & 3.6 & 0.2 \\
\hline
\end{tabular}

1. Values are given as mean \pm SEM.

2. Values in rows were not significantly different $(p>0.05)$.

3. Abbreviations and definitions: newly diagnosed: breast cancer patients who are not exposed to any type of interventions; recently diagnosed: breast cancer patients within 3 months of diagnosis who are either exposed (chemo) or not exposed (non-chemo) to chemical therapy; SEM: stander error of mean; HOMA: homeostasis model assessment according to the following formulas: $\log (\mathrm{HOMA})$ as $\log [\mathrm{FBG}(\mathrm{mmol} / \mathrm{L}) \times \mathrm{FBI}(\mu \mathrm{U} / \mathrm{ml}) / 22.5]^{12}$ 
Table 2. The prevalence of hyperleptinaemia in the study sample according to body mass index and treatment exposure ${ }^{(1-3)}$

\begin{tabular}{|c|c|c|c|c|c|c|c|c|c|c|}
\hline \multirow{3}{*}{ BMI Category ${ }^{11}$} & \multirow{2}{*}{\multicolumn{2}{|c|}{$\begin{array}{c}\text { Newly } \\
\text { diagnosed } \\
(\mathrm{N}=134) \\
\end{array}$}} & \multicolumn{6}{|c|}{ Recently diagnosed $(\mathrm{N}=262)$} & \multirow{2}{*}{\multicolumn{2}{|c|}{$\begin{array}{l}\text { Whole sample } \\
\qquad(\mathrm{N}=396)\end{array}$}} \\
\hline & & & \multicolumn{2}{|c|}{$\begin{array}{c}\text { Non- chemo } \\
\quad(\mathrm{N}=86)\end{array}$} & \multicolumn{2}{|c|}{$\begin{array}{l}\text { Chemo } \\
(\mathrm{N}=176)\end{array}$} & \multicolumn{2}{|c|}{$\begin{array}{c}\text { Total } \\
(\mathrm{N}=262)\end{array}$} & & \\
\hline & $\mathrm{n}$ & $\%$ & $\mathrm{n}$ & $\%$ & $\mathrm{n}$ & $\%$ & $\mathrm{n}$ & $\%$ & $\mathrm{n}$ & $\%$ \\
\hline Under weight $(<18.5)$ & 0 & 0.0 & 0 & 0.0 & 0 & 0.0 & 0 & 0.0 & 0 & 0.0 \\
\hline Normal weight (18.5-24.99) & 0 & 0.0 & 1 & 1.2 & 2 & 1.1 & 3 & 1.1 & 3 & 0.8 \\
\hline Overweight (25 -29.99) & 10 & 7.5 & 5 & 5.8 & 10 & 5.7 & 15 & 5.7 & 25 & 6.3 \\
\hline Obese $^{*}(\geq 30)$ & 28 & 20.9 & 9 & 10.5 & 40 & 22.7 & 49 & 18.7 & 77 & 19.4 \\
\hline Total sample * & 38 & 28.4 & 15 & 17.4 & 52 & 29.5 & 67 & 25.6 & 105 & 26.5 \\
\hline
\end{tabular}

1. Values are given as number of patients (n) and their percentages out of $(\mathrm{N})$.

2. $\left(^{*}\right)$ hyerleptinaemia among non-chemo was significantly $(p<0.05)$ lower than chemo and newly diagnosed groups.

3. Abbreviations and definitions: newly diagnosed: breast cancer patients who are not exposed to any type of interventions; recently diagnosed: breast cancer patients within 3 months of diagnosis who are either exposed (chemo) or not exposed (nonchemo) to chemical therapy; BMI: body mass index category11; hyperleptinaemia is defined as leptin level higher than $11.1 \mathrm{ng} / \mathrm{ml}^{13}$

Table 3. Mean and frequency distribution of leptin level in pre- and postmenopausal women according to treatment exposure ${ }^{(1-3)}$

\begin{tabular}{|c|c|c|c|c|c|c|c|c|c|c|c|c|}
\hline \multirow[b]{2}{*}{ Variable } & \multicolumn{4}{|c|}{ Newly diagnosed $(\mathrm{N}=134)$} & \multicolumn{4}{|c|}{ Recently diagnosed $(\mathrm{N}=262)$} & \multicolumn{4}{|c|}{ Whole sample $(\mathrm{N}=396)$} \\
\hline & \multicolumn{2}{|c|}{$\begin{array}{c}\text { Pre- } \\
\text { menopause } \\
(\mathrm{N}=80)\end{array}$} & \multicolumn{2}{|c|}{$\begin{array}{c}\text { Post- } \\
\text { menopause } \\
(\mathrm{N}=54)\end{array}$} & \multicolumn{2}{|c|}{$\begin{array}{c}\text { Pre- } \\
\text { menopause } \\
(\mathrm{N}=149)\end{array}$} & \multicolumn{2}{|c|}{$\begin{array}{c}\text { Post- } \\
\text { menopause } \\
(\mathrm{N}=113)\end{array}$} & \multicolumn{2}{|c|}{$\begin{array}{c}\text { Pre- } \\
\text { menopause } \\
(\mathrm{N}=229)\end{array}$} & \multicolumn{2}{|c|}{$\begin{array}{c}\text { Post- } \\
\text { menopause } \\
(\mathrm{N}=167)\end{array}$} \\
\hline \multirow{2}{*}{$\begin{array}{l}\text { Leptin* } \\
(\mathrm{ng} / \mathrm{ml})\end{array}$} & $\mathrm{Me}$ & SEM & Mea & SEM & Mec & SEM & $\mathrm{Me}$ & SEM & $\mathrm{Me}$ & SEM & $\mathrm{Me}$ & SEM \\
\hline & 8.1 & 0.7 & 10.9 & 1.0 & 8.0 & 0.4 & 8.1 & 0.6 & 8.0 & 0.4 & 9.0 & 0.5 \\
\hline \multirow{2}{*}{$\begin{array}{l}\text { Leptin }^{*}> \\
11.1(\mathrm{ng} / \mathrm{ml})\end{array}$} & $\mathrm{n}$ & $\%$ & $\mathrm{n}$ & $\%$ & $\mathrm{n}$ & $\%$ & $\mathrm{n}$ & $\%$ & $\mathrm{n}$ & $\%$ & $\mathrm{n}$ & $\%$ \\
\hline & 16 & 11.9 & 22 & 16.4 & 35 & 13.4 & 32 & 12.3 & 51 & 12.9 & 54 & 13.6 \\
\hline
\end{tabular}

1. Values are given as number of patients $(n)$ and their percentages out of $(N)$ also values are given as mean \pm SEM.

2. $\left(^{*}\right)$ Significant differences $(p<0.05)$ between pre and postmenopausal women for newly diagnosed study group.

3. Abbreviations and definitions: newly diagnosed: breast cancer patients who are not exposed to any type of interventions; recently diagnosed: breast cancer patients within 3 months of diagnosis who are either exposed (chemo) or not exposed (non-chemo) to chemical therapy; hyperleptinaemia is defined as leptin level higher than $11.1 \mathrm{ng} / \mathrm{ml}^{13}$.

The prevalence of hyperleptinaemia in the study sample according to body mass index and treatment exposure is shown in Table 2. The hyperleptinaemia was defined as leptin $>11.1 \mathrm{ng} / \mathrm{ml}$ (13). Considering the whole sample, the prevalence of hyperleptinaemia was $26.5 \%$ and it was more prevalent in obese $(19.4 \%)$ and overweight $(6.3 \%)$ patients than in subjects with normal weight $(0.8 \%)$. The frequency distribution of hyperleptinaemia was significantly lower $(p<0.05)$ in non-chemo group than in newly diagnosed and chemo groups among obese patients (10.5\% vs. $20.9 \%$ and $22.7 \%$ ), and in the total sample (17.4\% vs. $28.4 \%$ and $29.5 \%$ ), respectively.

Mean and frequency distribution of leptin level in pre- and postmenopausal women according to treatment exposure are given in Table 3. Leptin level and hyperleptinaemia in newly diagnosed group were higher $(p<0.05)$ among postmenopausal than premenopau- 
sal BC patients $(10.9 \pm 1.0$ vs. $8.1 \pm 0.7 \mathrm{ng} / \mathrm{ml})$ and $(16.4 \%$ vs. $11.9 \%$ ), respectively, whereas among recently diagnosed group and the whole sample, leptin level was insignificantly different $(p>0.05)$ among postmenopausal and premenopausal BC patients.

Age-controlled partial correlation coefficients between obesity indices, selected biomarkers and leptin according to treatment exposure are shown in Table 4. Leptin level was strongly correlated $(p<0.05)$ with BMI $(\mathrm{r}=0.38)$, WC $(\mathrm{r}=0.33)$, WHtR $(\mathrm{r}=0.31)$ and HOMA $(\mathrm{r}=$ 0.21 ) in newly diagnosed BC patients, while in recently diagnosed BC patients it was strongly correlated $(\mathrm{p}<$ $0.05)$ with WC $(r=0.38)$, BMI $(r=0.31)$ and WHtR $(r=$ $0.27)$. In the whole study sample, leptin level was correlated $(\mathrm{p}<0.05)$ with $\mathrm{BMI}(\mathrm{r}=0.34)$, WC $(\mathrm{r}=0.35)$, WHtR $(r=0.28)$, WHpR and HOMA $(r=0.21)$.

Table 4. Age-controlled partial correlation coefficients between obesity indices, selected biomarker and leptin according to treatment exposure ${ }^{(1-2)}$

\begin{tabular}{|c|c|c|c|c|c|c|}
\hline $\begin{array}{l}\text { Leptin hormone (ng/ml) } \\
\text { among study groups }\end{array}$ & BMI & WC & WHpR & WHtR & HOMA & C-peptide \\
\hline Newly-diagnosed $(\mathrm{N}=134)$ & $0.38^{* * *}$ & $0.33^{* * *}$ & 0.04 & $0.31^{* * *}$ & $0.21^{*}$ & -0.03 \\
\hline \multirow{4}{*}{$\begin{array}{l}\text { Recently-diagnosed: }(\mathrm{N}=262) \\
\text { Recently: Non-chemo }(\mathrm{N}=86) \\
\text { Recently: Chemo }(\mathrm{N}=176) \\
\text { Whole sample }(\mathrm{N}=396)\end{array}$} & $0.31^{* * *}$ & $0.38^{* * *}$ & $0.17^{* *}$ & $0.27^{* * *}$ & 0.06 & 0.05 \\
\hline & 0.01 & $0.17^{*}$ & $0.10^{*}$ & $0.13^{*}$ & 0.08 & -0.01 \\
\hline & $0.40^{* * *}$ & $0.43^{* * *}$ & $0.18^{*}$ & $0.30^{* * *}$ & 0.07 & 0.05 \\
\hline & $0.34^{* * *}$ & $0.35^{* * *}$ & $0.12^{*}$ & $0.28^{* * *}$ & $0.12^{*}$ & 0.01 \\
\hline
\end{tabular}

1. ${ }^{*}:(p<0.05) ; * *:(p<0.01) ;{ }^{* * *}:(p<0.001)$.

2. Abbreviations and definitions: newly diagnosed: breast cancer patients who are not exposed to any type of interventions; recently diagnosed: breast cancer patients within 3 months of diagnosis who are either exposed (chemo) or not exposed (non-chemo) to chemical therapy; BMI: body mass index; WC: waist circumferences cm; WHtR: waist to height ratio; WHpR: waist to hip ratio; HOMA: homeostasis model assessment according to the following formulas: $\log (\mathrm{HOMA})$ as $\log [\mathrm{FBG}(\mathrm{mmol} / \mathrm{L}) \times \mathrm{FBI}(\mu \mathrm{U} / \mathrm{ml}) / 22.5]^{12}$.

\section{DISCUSSION}

Leptin is a neuropeptide hormone that acts through binding to receptors in the hypothalamus and peripheral tissues (1). It has a major role in weight control, energy homoeostasis and many metabolic functions (2, $3)$. In the present study, the prevalence of hyperleptinaemia, leptin level more than $11.1 \mathrm{ng} / \mathrm{ml}$, is almost $27 \%$ in the total sample (13). Previous studies have shown that leptin and leptin receptors are overexpressed in BC tissue compared to the normal breast tissue $(5,14)$. Studies have revealed that leptin can enhance endothelial cell growth and suppress apoptosis in addition to the neoangiogenesis and mutagenic effect of leptin, which may explain the linkage between hyperleptinaemia and BC $(3,5,15)$.

The mean value of serum leptin $(\mathrm{ng} / \mathrm{ml})$ in the whole sample was $8.5 \pm 0.03$ and it was significantly lower in non-chemo $(7.1 \pm 0.05)$ than chemo $(8.6 \pm 0.5)$ and newly diagnosed $(9.2 \pm 0.6) \mathrm{BC}$ patients. These results were lower compared to that of a study by Carroll et al. who have found that the median values of leptin $(\mathrm{ng} / \mathrm{ml})$ after surgical treatment of BC were 13.8 (4.5-23.1) in normal weight patients, 33.0 (18.9-38.4) in centrally obese patients, and 56.1 (34.9-78.34) in BC patients (7). The results of this study were also low compared with studies conducted in women without BC (16). Leptin level was found to decrease in response to malnourished status (16-18).

In this study, BC patients were expected to be at risk of malnourishment due to the low dietary intakes during the first three months of diagnosis as patients try to understand and adapt to this disease and its consequences; this may explain the low mean level of leptin found in this study. Leptin in this manner could be used as a predictor of malnutrition risk in BC patients (19).

In the present study, leptin was correlated with all obesity indices including BMI, WC, WHpR and WHtR. In newly diagnosed BC patients, leptin had the 
highest correlation with BMI $(\mathrm{r}=0.38, \mathrm{p}<0.05)$, whereas in the recently diagnosed it was highly correlated with $\mathrm{WC}(\mathrm{r}=0.38, \mathrm{p}<0.05)$. These results agree with a prospective study by Goodwin et al. on $471 \mathrm{BC}$ women, aged 26-74 years, after surgical treatment, who showed that leptin was strongly correlated with BMI $(\mathrm{r}=0.81, \mathrm{p}<$ 0.05) (20). Furthermore, it has been observed by Wu et al. that leptin was positively correlated with obesity indices such as BMI $(r=0.59, p<0.05)$, WC $(r=0.50, p<0.05)$ and WHR $(r=0.23, p<0.05)(4)$.

In this study, leptin level was correlated with insulin resistance. Many studies have shown similar results $(21,22)$. This correlation may be related to the enhanced effect of hyperinsulinemia and insulin resistance to glucose utilization by adipose tissue that eventually lead to increased adipocyte mass and then increased production of adipocyte leptin $(6,23)$. Considering the high prevalence of obesity and insulin resistance among BC patients in Jordan as has been shown by previous studies $(24,25)$, further studies about the interaction between obesity, insulin resistance and leptin hormone among Jordanian must be done.

In the current study, leptin level was higher ( $p$ > 0.05 ) in postmenopausal women than in premenopausal women. This finding is consistent with the finding of previous study that reported a positive correlation between leptin and postmenopausal status in BC subjects $(4,26,27)$. This may be due to positive regulation of leptin of aromatase activity (28). Furthermore, Petridou et al. observed a negative correlation between leptin and
BC in premenopausal women but not in postmenopausal women (29), whereas Stattin et al. reported an insignificant association between leptin and menopausal status (30). The variation among results may be due to the differences in ethnicity, study population, design, sample size and sampling technique. This study is the first in Jordan and nearby region that investigates the influence of neuropeptide hormone on anthropometrics and biochemical measurements after treatment exposure; however, it is limited by the observational study design and being performed in only one tertiary hospital.

In conclusion, hyperleptinaemia is prevalent among $B C$ patients and the risk increased with body weight and age as it was positively correlated with all obesity indices in $B C$ patients and it was higher in postmenopausal $\mathrm{BC}$ women. The mechanisms underlying the association between $\mathrm{BC}$ and leptin hormone are not fully understood as many confounding factors share the two conditions such as obesity and insulin resistance which are associated with $B C$ severity and mortality. The leptin hormone was decreased after treatments exposure which may be considered as a biomarker for $\mathrm{BC}$ prognosis after exposure for treatments. Leptin hormone may need a closer attention by health care providers to improve outcomes after diagnosis and treatment exposure.

\section{Conflict of interest:}

None declared. 


\section{References}

1. Murakami T, Yamashita T, Iida M, et al. A short form of leptin receptor performs signal transduction. Biochem Biophys Res Commun 1997; 231: 26-9. https://doi.org/10.1006/bbrc.1996.6030

2. Zamboni M, Zoico E, Fantin F, et al. Relation between Leptin and the Metabolic Syndrome in Elderly Women. J Gerontol Med Sci 2011; 59: 396-400. https://doi.org/10.1093/gerona/59.4.M396

3. Artac M, Altundag K. Leptin and breast cancer: an overview. Med Oncol 2012; 29: 1510-4. https://doi.org/10.1007/s12032-011-0056-0

4. Wu M, Chou C, Chou Y, et al. Circulating levels of leptin, adiposity and breast cancer risk. Br J Cancer 2009; 100: 578-82. https://doi.org/10.1038/sj.bjc.6604913

5. Garofalo C, Surmacz E. Leptin and Cancer. JCel Physiol 2006; 207:12-22.

http://doi.org/10.1002/jcp.20472

6. Anubhuti, Arora S. Leptin and its metabolic interactions. Diabetes Obes Metab 2008; 10: 973-93. https://doi.org/10.1111/j.1463-1326.2008.00852.x

7. Carroll PA, Healy L, Lysaght J, et al. Influence of the metabolic syndrome on leptin and leptin receptor in breast cancer. Mol Carcinog 2011; 50: 643-51. https://doi.org/10.1002/mc.20764

8. Park HY, Kwon HM, Lim HJ et al. Potential role of leptin in angiogenesis: leptin induces endothelial cell proliferation and expression of matrix metalloproteinases in vivo and in vitro. Exp Mol Med 2011; 33:95-102.

https://doi.org/10.1038/emm.2001.17

9. Al-Tarawneh M, Arkoob K, Al-Nsour M, et al. Epidemiology of breast cancer in women in Jordan: patient characteristics and survival analysis. EMH J 2009; 16 : 1032-8.

10. Lee RD, Nieman DC. Nutrational Assessement, $5^{\text {th }}$ ed, New Yourk: McGraw-Hill. 2010.
11. Obesity: Preventing and Managing the Global Epidemic. 2000, World Health Organization, Report of a WHO Consultation (WHO Technical Report Series 894)

http://www.who.int/nutrition/publications/obesity/ WHO_TRS_894/en/

12. Matthews DR. Homeostasis model assessment: insulin resistance and beta-cell function from fasting plasma glucose and insulin concentrations in man. Diabetologia 1985; 28: 412-9. https://doi.org/10.1007/BF00280883

13. Lyoussi B, Ragala M, M'guil M, et al. Gender-Specific Leptinemia and Its Relationship with Some Components of the Metabolic Syndrome in Moroccans. Clin Exp Hypertens. 2005; 4: 377-94. https://doi.org/10.1081/CEH-57441

14. Yun J, Kimm H, Jo J, Jee S. Serum leptin is associated with metabolic syndrome in obese and non-obese Korean populations. Metabolism 2010; 59:424-9. https://doi.org/10.1016/j.metabol.2009.08.012

15. Surmacz E. Obesity hormone leptin: a new target in breast cancer? Breast Cancer Res 2007; 9:301. https://doi.org/10.1186/bcr1638

16. Amirkalali B, Sharifi F, Fakhrzadeha H, et al. Low serum leptin serves as a biomarker of malnutrition in elderly patients. Nutr Res.2010; 30: 314-9. https://doi.org/10.1016/j.nutres.2010.05.002

17. Cederholm T, Arner P, Palmblad J. Low circulating leptin levels in protein-energy malnourished chronically ill elderly patients. J Intern Med 2003; 242:37782.

https://doi.org/10.1046/j.1365-2796.1997.00216.x

18. Bouillanne O, Golmard J, Coussieu C, et al. Leptin a new biological marker for evaluating malnutrition in elderly patients. Eur J ClinNutr 2006; 61: 647-54. https://doi.org/10.1038/s.ejcn.1602572

19. Al-Zeidaneen S, Ahmad M, Al-Ebouse A. The risk of malnutrition among breast cancer women as related to their dietary intakes in Jordan. 2015 Conference: 
The 7th Conference on Scientific Research in Jordan. Organized by The Jordan Society for Scientific Research. At: Middle East University, Amman, Jordan.

20. Goodwin PJ, Ennis M, Fantus IG. Is leptin a mediator of adverse prognostic effects of obesity in breast cancer?. J Clin Oncol 2005; 23: 6037-42.

https://doi.org/10.1200//CO.2005.02.048

21. Considine R, Sinha M, Heiman M. Serum immunoreactive-leptin concentrations in normal-weight and obese humans. N Engl J Med 1996; 334: 292-5. https://doi.org/10.1056/NEJM199602013340503

22. Kahn B, Flier J. Obesity and insulin resistance. J Clin Invest 2000; 106: 473-81.

https://doi.org/10.1172/JCI10842

23. Mueller W, Gregoire F, Stanhope K. Evidence that glucose metabolism regulates leptin secretion from cultured adipocytes. Endocrinology 1998; 139:551-8. https://doi.org/10.1210/endo.139.2.5716

24. Al-Zeidaneen S, Ahmad M, Al-Ebouse A, et al. Interactive role of obesity indices on breast cancer severity in Jordanian women. EJBPS 2017; 4: 637-44.'

25. Al-Zeidaneen S, Ahmad M, Al-Ebouse A. The Impact of Treatment Exposure on Diabetes Bio-markers among Jordanian Breast Cancer Women: A Connection through FBG, C-Peptide and HOMA-IR. Curr Gynecol Oncol 2017;15: p. 231-238. https://doi.org/10.15557/CGO.2017.0022
26. Tessitore L, Vizio B, Jenkins O, et al. Leptin expression in colorectal and breast cancer patients. Int $\mathrm{J}$ Mol Med 2000; 5: 421-6.

https://doi.org/10.3892/ijmm.5.4.421

27. Han C, Zhang HT, Du L, et al. Serum levels of leptin, insulin, and lipids in relation to breast cancer in China. Endocrine 2005; 26:19-24. https://doi.org/10.1385/ENDO:26:1:019

28. Catalano S, Marsico S, Giordano C. Leptin enhances, via $\mathrm{AP}-1$, expression of aromatase in the MCF-7 cell line. J Biol Chem 2003; 278: 28668-76. https://doi.org/10.1074/jbc.M301695200

29. Petridou E, Papadiamantis Y, Markopoulos C, et al. Leptin and insulin growth factor I in relation to breast cancer (Greece). Cancer Causes Control 2000; 11: 383-8.

https://doi.org/10.1023/A:1008903727238

30. Stattin P, Soderberg S, Biessy C, et al. Plasma leptin and breast cancer risk: A prospective study in northern Sweden. Breast Cancer Res Treat 2004; 86: 191-6. https://doi.org/10.1023/B:BREA.0000036782.11945.d7 


\title{
Procena uticaja lečenja na hormon neuropeptid leptin i rizik od gojaznosti kod žena sa karcinomom dojke u Jordanu
}

\author{
Safa'a A. Al-Zeidaneen ${ }^{1}$, Mousa N. Ahmad², Ali D. Al-Ebous ${ }^{3}$ \\ ${ }^{1}$ Departman objedinjenih medicinski nauka, Univerzitetski koledž Al-Zarqa, Primenjeni univerzitet Al-Balqa, Jordan \\ ${ }^{2}$ Departman za nutricionizam i tehnologiju hrane, Fakultet za agrikulturu, Univerzitet u Jordanu, Amman, Jordan \\ ${ }^{3}$ Odeljenje za lečenje kancera dojke, Departman za opštu hirurgiju, Medicinski centar King Hussein, Amman, Jordan
}

\section{SAŽETAK}

Kancer dojke je najčešći životno ugrožavajući maligni tumor kod žena. Malo se zna o vezi između hormona neuropeptida leptina i razvoja karcinoma dojke. Cilj rada je bila procena interaktivne uloge neuropeptida leptina u odnosu na lečenje i menopauzu kod žena sa karcinomom dojke u Jordanu. Opservaciona studija uključila je 398 bolesnica sa karcinomom dojke (starosti od 25 do 65 godina) lečenih na klinikama za karcinom dojke. Eksperimentalna studija je uključila 134 novodijagnostikovane bolesnice sa karcinomom dojke koje nisu prethodno lečene i 262 bolesnice $u$ toku prva tri meseca lečenja kojima je neposredno pre toga dijagnostikovan karcinom dojke. Za kvantitavno određivanje nivoa leptina korišćen je ELISA test.

Prevalencija hiperleptinemije - nivo leptina iznad 11,1ng/ml, bila $27 \%$ je, dok je srednja vrednost leptina u serumu (ng/ml) u celom uzorku bila 8,5 $\pm 0,03$ i bila je nesignifikatno niža kod bolesnica koje nisu lečene hemoterapijom $(7,1 \pm 0,05)$ nego kod bolesnica koje su lečene ovom terapijom $(8,6 \pm 0,5)$ i kod novodijagnostikovanih bolesnica $(9,2 \pm 0,6)$. Leptin je bio u pozitivnoj korelaciji sa indeksima gojaznosti uključujući BMI, WC, WHpR i WHtR. Kod novodijagnostikovanih bolesnica, leptin je bio u najvišoj korelaciji sa BMI r=0,38; $p<0$,05, dok je kod bolesnica kod kojih je neposredno pre toga bolest bila dijagnostikovana, leptin bio u visokoj korelaciji sa $\mathrm{WC}(\mathrm{r}=0,38 ; \mathrm{p}<0,05)$.

Leptin je bio u pozitivnoj korelaciji sa sa indeksima gojaznosti kod bolesnica sa karcinomom dojke i njegove vrednosti su bile povišene kod žena u menopauzi sa karcinomom dojke. Vrednosti leptina su bile snižene nakon lečenja, te se ovaj hormon može smatrati biomarkerom za prognozu karcimoma dojke i odgovor na lečenje. Zdravstveni radnici treba da obrate više pažnje na ovaj hormon kako bi se poboljšao ishod ove bolesti nakon donošenja dojagnoze i lečenja.

Ključne reči: karcinom dojke, lečenje karcinom, hormon leptin, neuropeptid, gojaznost, postmenopauza 